\title{
Hanseniella lanceolata sp.n. (Myriapoda: Symphyla) found in a European hothouse
}

\section{Hanseniella lanceolata sp.n. (Myriapoda: Symphyla), вид, найденный в тропической оранжерее в Европе}

\author{
Martin Soesbergen \\ М. Сусбэрхын
}

European Invertebrate Survey Netherlands, Karveel 12-38, 8231 AS Lelystad, The Netherlands. E-mail: martin.soesbergen01@rws.nl Европейская исследовательская служба Нидерландов по беспозвоночным.

KEY WORDS: Scutigerellidae, new species, Hanseniella oligomacrochaeta, Symphylella vulgaris. КЛЮЧЕВЫЕ СЛОВА: Scutigerellidae, новый вид, Hanseniella oligomacrochaeta, Symphylella vulgaris.

ABSTRACT. A new species of the symphylan genus Hanseniella Bagnall, 1913 is described. It was found in a hothouse of a small zoo at Almere, the Netherlands. Hanseniella oligomacrochaeta Scheller, 2002 was recorded, for the first time since its description, in another Dutch hothouse. A bibliographic catalogue of all 82 Hanseniella species known to date is presented.

How to cite this article: Soesbergen M. 2019. Hanseniella lanceolata sp.n. (Myriapoda: Symphyla) found in a European hothouse // Arthropoda Selecta. Vol.28. No.1. P.27-36. doi: 10.15298/arthsel. 28.1.04

РЕЗЮМЕ. Описан новый вид симфил рода Hanseniella Bagnall, 1913. Он был найден в маленьком зоопарке в Алмере (Нидерланды). Вид Hanseniella oligomacrochaeta Scheller, 2002 впервые обнаружен со времени его описания в еще одной голландской оранжерее. Представлен библиографический каталог всех 83 известных до сих пор видов рода Hanseniella.

\section{Introduction}

Symphylans in hothouses have received little attention in comparison to other myriapods. Four hothouses in the Netherlands have recently been investigated: Luttelgeest Orchid Farm; Almere Jungle Zoo; University of Utrecht Botanical Garden; University of Amsterdam Botanical Garden. From two of these hothouses (Amsterdam and Utrecht), the diplopod and isopod faunas are known to be rich [Berg et al., 2008] and the same was expected of the symphylan fauna. None, however, were found. Symphylans were only revealed in the two other hothouses, where they were very rare. One of the species found is known from hothouses in London [Shaw, 1961], Berlin [Scheller, 2002] and Tomsk [Nefediev et al., 2016]. The second species was only reported from Berlin [Scheller, 2002]. The third species is new to science.

\section{Systematics}

The four animals collected belong to two genera and three species. Of the two animals from Luttelgeest, one is Symphylella vulgaris (Hansen, 1903) and the other Hanseniella oligomacrochaeta Scheller, 2002.

Animals from the Almere Jungle Zoo, belonging to the family Scutigerellidae, could not be identified to the species level. The Scutigerellidae consists of five genera [Camacho, 2010]. Comparison with these five genera showed that the Almere Jungle Zoo animals have:

- no u-shaped incision, and are, therefore, not Scutigerella [Edwards, 1959];

- neither angled tergites nor short styli, thus indicating that they are not Scolopendrelloides [Camacho, 2010];

- no sternal appendages, as would be the case with Millotellina [Naumann, Scheller, 1977];

- no disciform lobe on the last tergite as found in Scopoliella [Scheller, 1986].

Both animals from the Almere Jungle Zoo belong to Hanseniella Bagnall, 1913 and have only one pair of anterolateral macrochaetae on tergite 2 . Since there is no key to all of the known Hanseniella species, descriptions of 82 species [Szucsich, Scheller, 2011] were consulted. No new species have been described since 2011 [BioNames, 2018]. Only three of these species have a reduced number of anterolateral macrochaetae, with only one pair being anterolateral macrochaetae on segment 2. A complete list of Hanseniella species with the known positions of (anterolateral) macrochaetae on the tergites is in Appendix.

Family Scolopendrellidae Genus Symphylella Silvestri, 1902 1. Symphylella vulgaris (Hansen, 1903)

A widely distributed subcosmopolitan species [Camacho, VandenSpiegel, 2012]. Known from Europe, Asia, Africa, North America, Mexico and New Zealand 


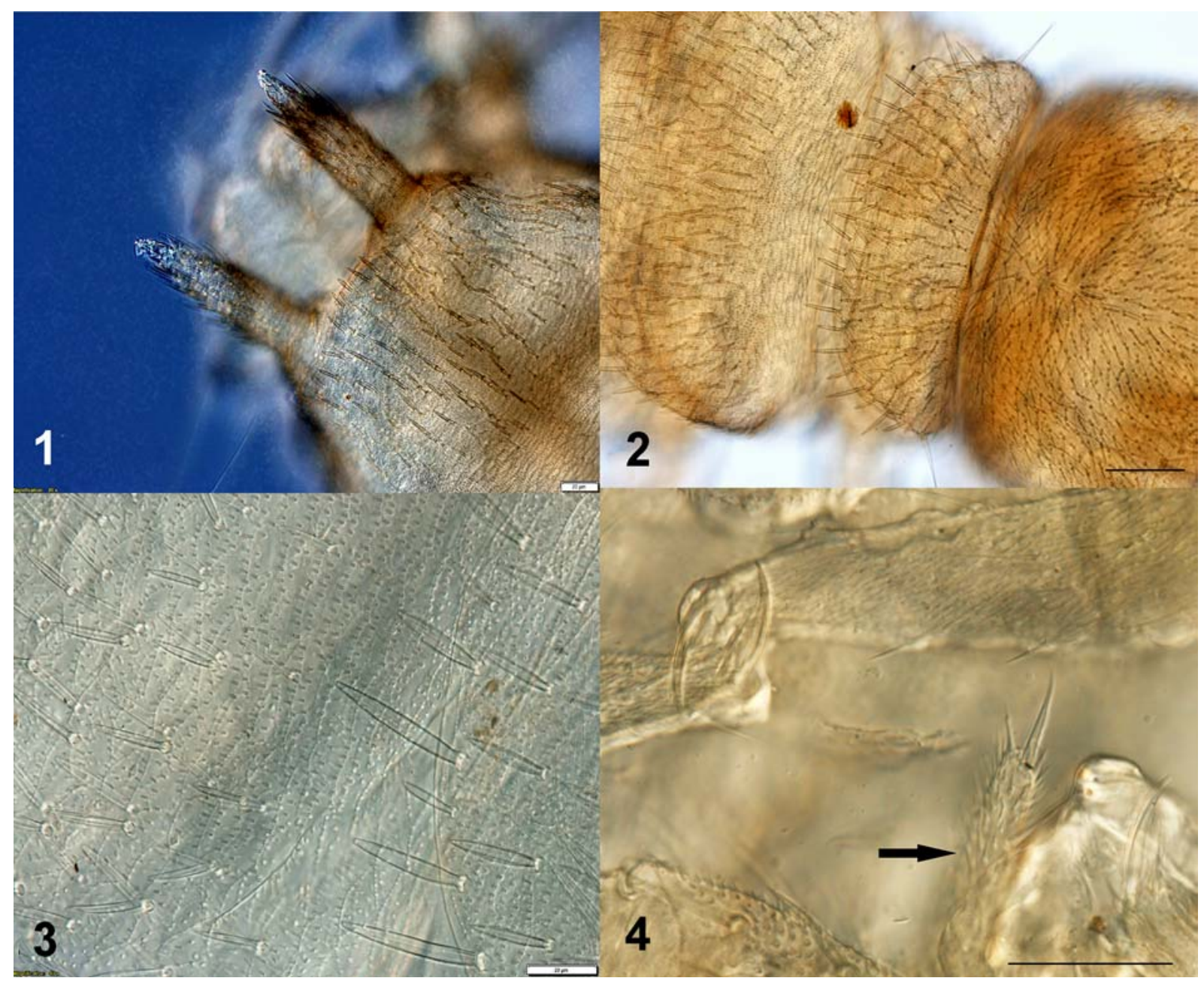

Figs 1-4. Hanseniella lanceolata sp.n., holotype. 1 - last segment; 2 - anterolateral macrochaetae on tergite 2; 3 - setae and pubescence on tergite 2; 4 - stylus indicated by arrow. Scale bars: $100 \mu \mathrm{m}(2)$ and $50 \mu \mathrm{m}(4)$.

Рис. 1-4. Hanseniella lanceolata sp.n., голотип. 1 - последний сегмент; 2 - переднебоковые макрохеты на тергите $2 ; 3$ щетинки и опушение на тергите 2; 4 - перо обозначено стрелкой. Масштаб: 100 мкм (2) и 50 мкм (4).

and the Atlantic islands of Madeira, Azores and St. Helena. The main distribution is in Europe where it occurs in natural habitats, common in gardens and hothouses [Hansen, 1903; Scheller, Stoev, 2006].

\section{Family Scutigerellidae}

Genus Hanseniella Bagnall, 1913

\section{Hanseniella oligomacrochaeta Scheller, 2002}

A species previously known only from a hothouse in Berlin [Scheller, 2002] where 19 specimens were caught. The Orchid Farm specimen is the first published record since the original description of the species and represents an addition to the Dutch fauna.

\section{Hanseniella lanceolata sp.n. \\ Figs 1-11.}

HOLOTYPE, Almere Jungle Zoo hothouse, Almere, the Netherlands, collected on 18.XI.2017, leg. M. Soesbergen.

PARATYPE, same data, together with holotype.
Slide preparations of the cleared animals are deposited in the collection of the Naturalis Biodiversity Centre Leiden, numbers RMNH.5092386 (holotype) and RMNH.5070501 (paratype).

On a second visit on 11.VI.2018, no more animals could be found.

DIAGNOSIS. Last segment (Fig. 1) rounded, with neither a u-shaped incision nor a depression. Only one pair of anterolateral macrochaetae on segment 2 (Fig. 2) and no anterolateral macrochaetae on other segments. Setae on dorsal side of tergites fusiform. Tergites with pubescence among these setae, mostly placed on ridges (Fig. 3). Stylus with two terminal spines, unequal of length, and one long lateral spine (Fig. 4).

TYPE LOCALITY. Almere Jungle Zoo hothouse, Almere, the Netherlands.

NAME. From Latin "lanceolata" = lance or spear, referring to the lanceolate shape of the setae on the tergites; adjective in feminine gender.

DESCRIPTION. Length: Body without cerci and antennae $4.25 \mathrm{~mm}$ (holotype) and $3.75 \mathrm{~mm}$ (paratype).

Head. Rounded and slightly, 1.1 times, broader than long (Fig. 5), head densely granulate and setose. Central rod indistinct, formed by a smooth line without granules (Figs 5, 


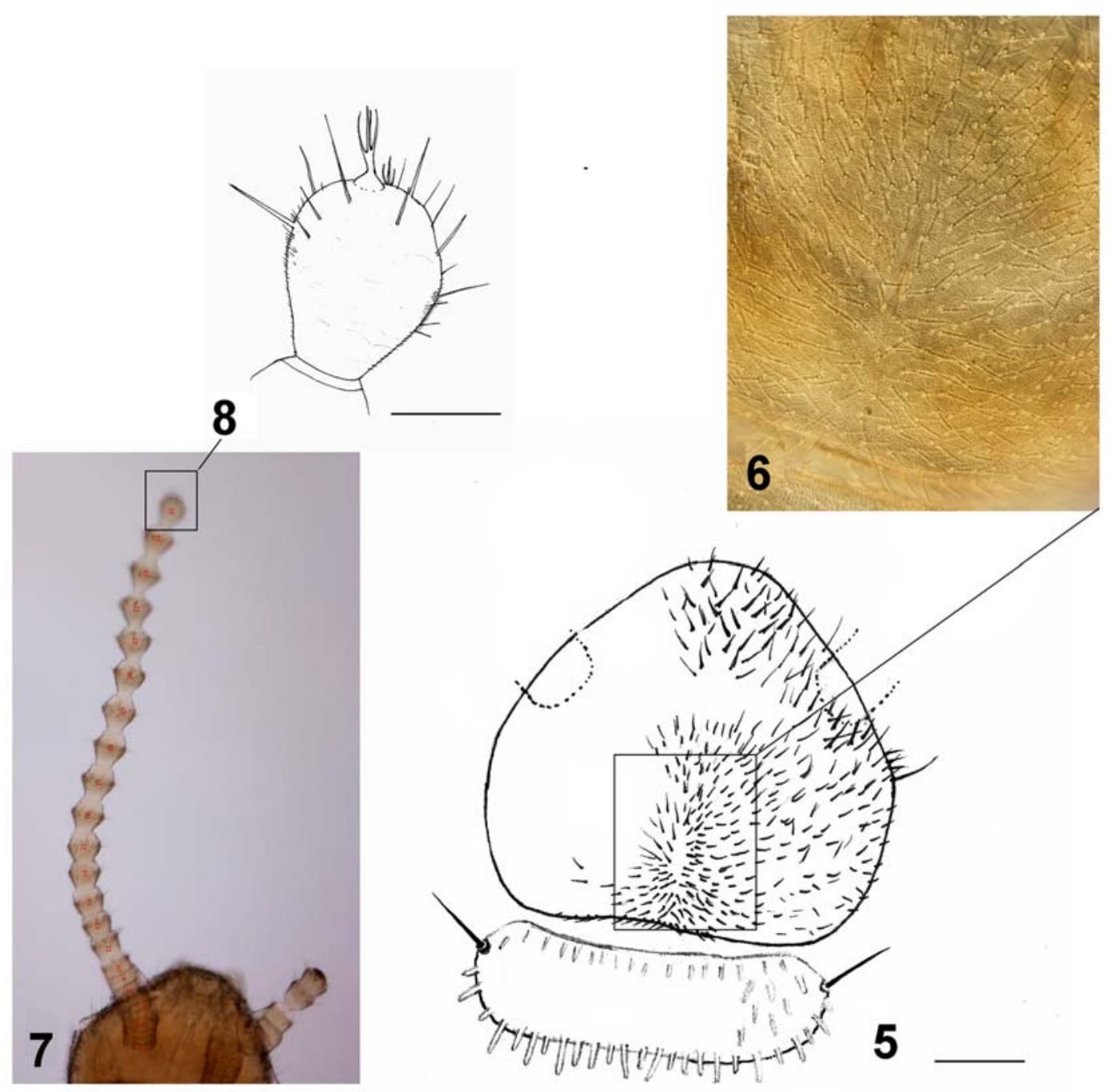

Figs 5-8. Structural details of head and tergite 2 of Hanseniella lanceolata sp.n., holotype. 5 - head and tergite $2 ; 6$ - central rod; 7 left antenna with 25 segments; 8 - last segment of antenna. Scale bars: $100 \mu \mathrm{m}(5)$ and $50 \mu \mathrm{m}(8)$.

Рис. 5-8. Структурные детали головы и тергита 2 у Hanseniella lanceolata sp.n., голотип. 5 - голова и тергит 2; 6 центральная ветвь; 7 - левый усик с 25 сегменами; 8 - последний членик усика. Масштаб: 100 мкм (5) и 50 мкм (8).

6). Setae at front and on top of head pointed. Setae on the front of head longer and placed less regularly, directed forward and outward from central rod. Setae in back part of head more blunt and lanceolate. One longer seta at median edge of head (Fig. 5) about twice as long as other setae. Setae on head finer than on tergites.

Antennae. Left one short, $1 / 3$ of body length, with 25 segments (Fig. 7). Right antenna of holotype broken off. Paratype with both antennae broken off. First ten segments broader than long. Segment 10 elongated, with some long setae. Segment 11 and following ones conical, each with a whorl of setae. Setae on inner and outer sides almost equal in length. Last segment spherical (Fig. 8), with one large apical four-spined organ on a circular protuberance. A second, much smaller, spined organ present as well.

Tergites. Tergite 1 rudimentary, with two setae. Tergite 2 complete, with a pair of anterolateral macrochaetae directed outward and forward (Fig. 5). Both equal in length (75 $\mu \mathrm{m}), 0.9$ diameter of antennomere 1 . Between anterolateral macrochaetae, 28 posteromarginal setae alternating in size.
Longer setae 0.6 times as long $(45-47 \mu \mathrm{m})$ as anterolateral macrochaetae. Shorter ones $0.3-0.4$ times as long (25-28 $\mu \mathrm{m})$ as anterolateral macrochaetae. All setae on tergites blunt lanceolate (parallel-sided and broadest before the middle) to somewhat fusiform (broadest in the middle and tapering thereafter). Most of larger setae lanceolate and some of the smaller more fusiform. Starting with tergite 3, alternation of long and shorter setae at hind edge less clear. Tergite 3 longer, length:breadth $=1: 1.6$. Segments 5,6 and 13 also longer. Tergites 4 and 7-12 shorter. Last tergite (Fig. 1) rounded, without u-shaped incision. Short fusiform pubescence between setae, this pubescence present on all segments and mostly located on cuticular ridges (Fig. 3).

Legs. With numerous large setae on trochanter, femur, coxa and tarsus (Fig. 9). Trochanter dorsally with, at the most, two setae on last leg. Tarsi regularly tapering distally. Tarsi with rows of 7-10 setae dorsally, proximally and ventrally. Tibiae stout, with setae on all sides. Femur short, with several setae on dorsal and proximal sides and one on ventral side. Claws unequal in size, the smaller one about $2 / 3$ 


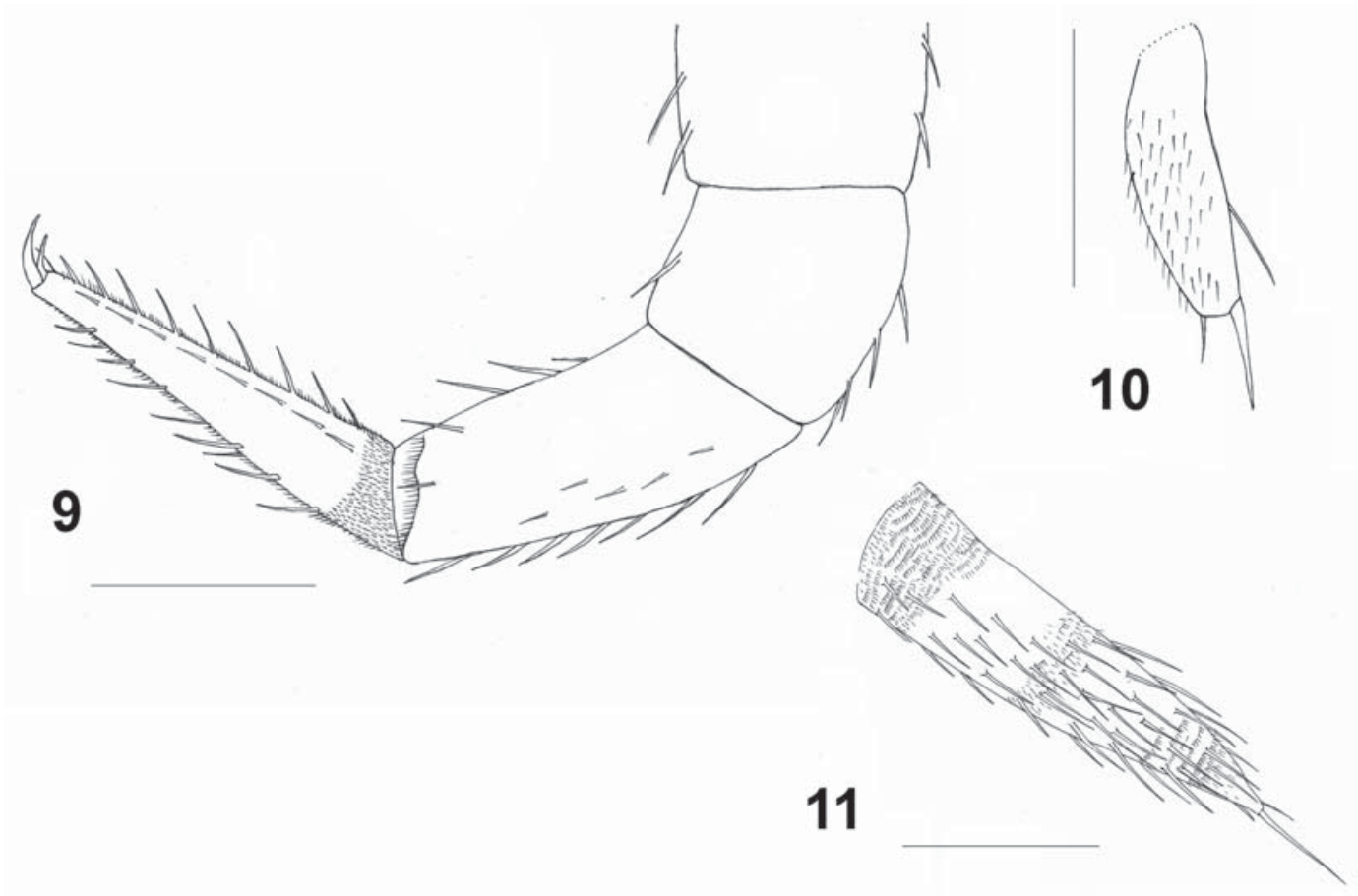

Figs 9-11. Leg and appendages of Hanseniella lanceolata sp.n., holotype (9 and 11) or paratype (10). 9 - last leg, pubescence only partly shown on tarsus; 10 - stylus; 11 - cercus, pubescence only partly drawn. Scale bars: $100 \mu \mathrm{m}(9$ and 11) and $50 \mu \mathrm{m}(10)$.

Рис. 9-11. Нога и конечности у Hanseniella lanceolata sp.n., голотип (9 и 11) или паратип (10). 9 - последняя нога, опушение показано только частично на лапке; 10 — перо; 11 — церка, опушение показано только частично Масштаб: 100 мкм (9 и 11) и 50 мкм (10).

the size of the longer one. Front seta almost as long as shorter claw. Trochanter, femur, coxa and tarsus with pubescence of short hairs.

Styli. About 3.5 times as long as broad and about 1.5 times as long as basis of tarsus. One side slightly concave, the other almost straight (Fig. 10). Two apical setae, the longer twice as long as the smaller one. On the straight side, a slender seta at $2 / 3$ of the length, about as long as the long apical seta.

Cerci. Conical and about 3.7 times as long as wide. On one side, 40-45 slightly curved setae, distal ones being longer than proximal ones. Distal setae $0.64 \pm 0.08(n=10)$ times as long as greatest diameter of cercus, vs. $0.44 \pm 0.04$ $(n=10)$ times in proximal ones. Setae not uniformly distributed and absent from first half on mesal side (Fig. 11) Pubescent with a glabrous top. Pubescence present as very small hairs among setae placed on and between transverse rows of cuticular ridges. Top seta on cerci 0.6 times as long as the greatest diameter of a cercus.

\section{AFFINITIES AND COMPARISONS}

Comparing the new species to known congeners, it is noteworthy that species with only anterolateral macrochaetae on tergite 2 are very rare. The three other species with only one pair of anterolateral macrochaetae on tergite 2 are as follows: Scutigerella (Hanseniella) hanseni (Bagnall, 1913). H. condylifera Scheller, 1971 and H. unichaetosa Scheller, 1971. Bagnall's [1913] description of $H$. hanseni is short and incomplete, in contrast to Scheller's [1971] descriptions of $H$. unichaetosa and $H$. condylifera. Both latter species are small, $H$. condylifera reaching $3.8 \mathrm{~mm}$ (mean $3.44 \mathrm{~mm}$ ) without antenna and cerci, H. unichaetosa averages $2.02 \mathrm{~mm}$ and reaches $3.04 \mathrm{~mm}$ [Scheller, 1971], vs. $4.65 \mathrm{~mm}$ in $H$. hanseni [Bagnall, 1913].

Hanseniella lanceolata sp.n. measures 3.75 to $4.25 \mathrm{~mm}$. The differences from the other three species are discussed, and comparisons given, in Table. The head of all four species is about as long as broad, with an indistinct central rod in three species, vs. unknown in H. hanseni. The end swelling in the new species is indistinct and elongated, vs. round to ovoid. The setae on the head are of different shapes, straight and pointed on the front, longer, slightly bent and blunt in the back part. In H. condylifera and H. unichaetosa, all are equal in length and pointed. In $H$. hanseni, they are short, fusiform and blunt. One longer seta is at the angle on the side of the head. In H. condylifera and H. unichaetosa, there are two longer setae. The number of antennomeres is much larger in $H$. hanseni (38), whereas $H$. unichaetosa has less, 22-23 segments.

Tergite 1 is reduced, with two setae, this character beings unknown in $H$. hanseni. Tergite 2 has one pair of long anterolateral macrochaetae, each 0.9 times the size of the basis of the antenna, pointed as in H. unichaetosa. The number and shape of setae between the anterolateral macrochaetae differs strongly, blunt and alternating in length. In $H$. condylifera and $H$. unichaetosa shorter, pointed and not alternating in length. The dense pubescence all over tergites, mostly placed on cuticular ridges, gives them a scaly appearance. In $H$. condylifera, the hind margin is glabrous and has a different pattern (Table). In H. unichaetosa, there is no pubescence on tergites.

The styli are with three setae, two distal and unequal in length and one lateral seta about the size of the long distal 
Table. Comparison of features in four species of Hanseniella.

Таблица. Сравнение признаков четырех видов Hanseniella.

\begin{tabular}{|c|c|c|c|c|}
\hline Features & H. condylifera & H. unichaetosa & H. hanseni & $\begin{array}{l}\text { H. lanceolata } \\
\text { sp.n. }\end{array}$ \\
\hline Length & $\begin{array}{c}2.78-(3.44)-3.80 \\
(n=29)\end{array}$ & $\begin{array}{c}1.80-(2.08)-3.13 \\
(\mathrm{n}=85)\end{array}$ & $4.65(n=1)$ & $3.75-4.25(n=2)$ \\
\hline \multicolumn{5}{|l|}{ Head } \\
\hline Shape & As long as broad & $\begin{array}{c}\text { About as long as } \\
\text { broad }\end{array}$ & $\begin{array}{c}\text { Ovate } 7 / 8 \text { as long } \\
\text { as broad }(1: 1.1)\end{array}$ & $\begin{array}{l}\text { About as long as } \\
\text { broad }(1: 1.1)\end{array}$ \\
\hline Central rod & $\begin{array}{l}\text { A very thin circular } \\
\text { to ovoid end swelling }\end{array}$ & $\begin{array}{l}\text { Thin, indistinct with a } \\
\text { round end swelling }\end{array}$ & Unknown & $\begin{array}{l}\text { Indistinct with a } \\
\text { lanceolate end } \\
\text { swelling }\end{array}$ \\
\hline Setae & $\begin{array}{c}\text { Dense, equal in } \\
\text { length and pointed, } \\
\text { lateral ones slightly } \\
\text { bent }\end{array}$ & $\begin{array}{l}\text { Dense, straight, equal } \\
\text { in length and pointed }\end{array}$ & $\begin{array}{l}\text { Short, blunt, } \\
\text { fusiform }\end{array}$ & $\begin{array}{l}\text { On front pointed, } \\
\text { in the rear blunt }\end{array}$ \\
\hline Setae at margin & $\begin{array}{c}\text { Two, dagger- or } \\
\text { blade-shaped, a little } \\
\text { longer }\end{array}$ & $\begin{array}{l}\text { Two longer setae } \\
\text { behind antenna }\end{array}$ & Unknown & One twice as long \\
\hline Segments antenna & $23-34$ & $22-23$ & 38 & 25 \\
\hline \multicolumn{5}{|l|}{ Body } \\
\hline Tergite 1 & Reduced with 2 setae & Reduced with 2 setae & Unknown & $\begin{array}{c}\text { Reduced with } 2 \\
\text { setae }\end{array}$ \\
\hline Tergite 2 & $\begin{array}{c}2.6-3.6 \mathrm{x} \text { as broad as } \\
\text { long }\end{array}$ & $\begin{array}{c}2.0-2.2 \mathrm{x} \text { as broad as } \\
\text { long }\end{array}$ & Unknown & $\begin{array}{c}2.7 \mathrm{X} \text { as broad as } \\
\text { long }\end{array}$ \\
\hline $\begin{array}{l}\text { - AM x length of } \\
\text { first segment } \\
\text { antenna }\end{array}$ & $0.6-0.7$ & $0.7-0,8$ & $<1.0$ & 0.9 \\
\hline- AM setae & Blunt & Pointed & Unknown & Pointed \\
\hline - setae between & $23-26$ & $15-19$ & Unknown & 28 \\
\hline - setae between & $\begin{array}{l}\text { Pointed, short (0.3- } \\
0.33 \text { AM) and } \\
\text { longest in the middle }\end{array}$ & $\begin{array}{l}\text { Pointed, short }(0.5 x \\
\text { AM) and equal in } \\
\text { length }\end{array}$ & Unknown & $\begin{array}{l}\text { Blunt, alternating } \\
\text { long }(0.5 \times \mathrm{AM}) \\
\text { and short }(0.25 \mathrm{x} \\
\mathrm{AM})\end{array}$ \\
\hline - dorsal setae & $\begin{array}{c}\text { Pointed anterior and } \\
\text { blunt posterior }\end{array}$ & Pointed and sparse & Short blunt & $\begin{array}{c}\text { Numerous blunt all } \\
\text { over }\end{array}$ \\
\hline - pubescence & $\begin{array}{l}\text { Distinct anteriorly, } \\
\text { partly in transverse } \\
\text { lines, posterior } \\
\text { reticulate. Rear } \\
\text { margin glabrous. }\end{array}$ & $\begin{array}{l}\text { No pubescence, but } \\
\text { finely granulated }\end{array}$ & Unknown & $\begin{array}{l}\text { Distinct, short, } \\
\text { blunt, partly } \\
\text { located on } \\
\text { cuticular ridges }\end{array}$ \\
\hline \multicolumn{5}{|l|}{ Appendages } \\
\hline Legs tarsus setae & $6(-8)$ & 5 & $10-12$ & $8-9$ \\
\hline Cerci l:b & $2.5-3.0 \mathrm{x}$ & $2.8-3.3 x$ & $4.0-4.5 x$ & $3.7-3.8 x$ \\
\hline $\begin{array}{l}\text { Cerci setae length } \\
\text { to depth of cerci }\end{array}$ & $0.4-0.5(0.6) x$ & $\begin{array}{c}0.6-0.8 \\
\text { increasing distally }\end{array}$ & $>0.5 x$ & $\begin{array}{c}0.5-0.7 \mathrm{x} \\
\text { increasing distally }\end{array}$ \\
\hline Cerci setae/side & $<15$ & $<10$ & Moderate $( \pm 20)$ & $30-36$ \\
\hline Cerci top & $\begin{array}{c}\text { Glabrous and } \\
\text { triangular }\end{array}$ & Glabrous and swollen & $\begin{array}{l}\text { Not clearly } \\
\text { drawn }\end{array}$ & $\begin{array}{c}\text { Glabrous and } \\
\text { conical }\end{array}$ \\
\hline Styli 1:b & $\begin{array}{c}2.4-2.9 \mathrm{x} \text { as long as } \\
\text { wide }\end{array}$ & $\begin{array}{c}3.2-3.3 \times \text { as long as } \\
\text { wide }\end{array}$ & Unknown & $\begin{array}{c}3.5-4.7 \mathrm{x} \text { as long as } \\
\text { wide }\end{array}$ \\
\hline Styli hairs & Pubescent & Finely pubescent & Unknown & Pubescent \\
\hline Styli setae & 2 & 2 & Unknown & 3 \\
\hline Coxal sacks & 7 pairs on legs $3-9$ & 7 pairs on legs 3-9 & Unknown & 7 pairs on legs $3-9$ \\
\hline
\end{tabular}

AM — anterolateral macrochaetae. 
one. The longest distal seta is $0.31-0.36$ times as long as the stylus, the shortest $0.4-0.5$ times the length of the longest. In $H$. condylifera, there are two distal setae unequal in length, the longest being 0.4 times the stylus length, the shortest 0.4 times as long as the longest seta. In $H$. unichaetosa, two distal setae are unequal in length, the longest being 0.6 times the stylus length, the shortest 0.5 times as long as the longest seta. Regrettably, these characters are unknown in H. hanseni.

The cerci support far more numerous setae than the other species. The cerci are more slender than in $H$. condylifera and $H$. unichaetosa, but broader than in $H$. hanseni.

The main differences between the four species lie in the shape and number of setae on the tergites and head, the number of setae on the cerci and the number of large setae on the styli. The new species differs readily from the other three species in question that show only a single pair of large anterolateral macrochaetae on tergite 2 (Table).

The affinities of $H$. lanceolata sp.n. lie not only with the above trio of congeners that share a reduced number of anterolateral macrochaetae, but also with another four species which show macrochaetae only on tergites 2 and 3 . These are $H$. appendicofera Scheller, 1971, H. cirrofera Scheller, 1971, H. oligomacrochaeta and $H$. silvicola Scheller, 1961 (see Scheller [2002]).

The stylus with a third seta $2 / 3$ as long as the straight side resembles that of $H$. pillipes Attems, 1937, $H$. afromontana Scheller, 1954, H. pulchra Rochaix, 1956 and $H$. natalensis Juperthie-Jupeaux, 1972. The first is a large $(9 \mathrm{~mm})$ species with (antero)lateral macrochaetae at least on tergites 2 to 9 [Attems, 1937]. The second species has long anterolateral macrochaetae on tergites 2, 3, 4, 6, 7 and 9 [Scheller, 1954]. The third species shows long anterolateral macrochaetae on tergites $2,3,4,6,7,9$ and 10 [Rochaix, 1956]. The last species has long anterolateral macrochaetae on tergites 2, 3, 6, 9 and 12 [Juperthie-Jupeaux, 1972]. All four are African taxa.

\section{Discussion}

The most common Hanseniella species in hothouses is H. caldaria (Hansen, 1903), described from a hothouse in Copenhagen [Hansen, 1903]. It is known from Belgium [Lock, 2010], France, Denmark, Monaco, England [Remy, 1942], Scotland [Hancock, 1999], Norway [Olsen et al., 2014] and Germany [Voigtländer et al., 2017]. This species has not yet been found in the Netherlands. Other species of Hanseniella known from hothouses are H. agilis Tiegs, 1939, H. oligomacrochaeta, H. orientalis (Hansen, 1903), and H. unguiculata (Hansen, 1903) [Shaw, 1961; Voigtländer et al., 2017]. An unidentified Hanseniella is known from a hothouse in Tomsk, Siberia [Nefediev et al., 2016]. Because the genus Hanseniella is widespread in the tropical and subtropical regions of the world, more species are probably to be found in hothouses. For species other than H. caldaris, particular care is needed when identifying specimens from hothouses.

\section{Acknowledgements}

I would like to thank Arnold Veen for the permission to use microscopes and take photographs at the laboratory of
Rijkswaterstaat Lelystad. Both Peter Hellyer, managing editor of the UAE environmental and history journal TRIBULUS, and Sergei Golovatch, Moscow, kindly edited an advanced draft and checked the English.

\section{References}

Adam M.O., Burtel J. 1956. A contribution to the study of the New Zealand Symphyla // Records of the Canterbury Museum. Vol.7. No.2. P.61-88.

Allan R.T. 1992. A new species of Hanseniella (Symphyla: Scutigerellidae) from the interior highlands of Arkansas // Entomological News. Vol.103. No.5. P.169-174.

Attems C. 1937. Chilopoden und Symphylen des Belgischen Congo // Revue de Zoologie et de Botanique Africaines. T.29. P.317-332.

Aubry M.J., Masson C. 1953. Contribution à la faune endogée de Madagascar. Symphyles // Mémoires de l'Institut Scientifique de Madagascar, Série A. Vol.8. P.43-66.

Bagnall R.S. 1913. A synopsis of the British Symphyla, with descriptions of new species // Transactions of the Natural History Society of Northumberland, Durham, and Newcastle-uponTyne, New Series. Vol.4. P.17-42.

Belfield W. 1988. Hanseniella ghanensis n. sp. from the Ashanti region, Ghana, W. Africa // Revue d'Ecologie et de Biologie du Sol. Vol.25. No.2. P.257-260.

Berg M.P., Soesbergen M., Tempelman D., Wijnhoven H. 2008.Verspreidingsatlas Nederlandse landpissebedden, duizendpoten en miljoenpoten (Isopoda, Chilopoda, Diplopoda) // EIS-Nederland, Leiden \& Vrije Universiteit, Amsterdam.

BioNames 2018. http://bionames.org/names/cluster/989968 Species with Hanseniella as genus. Retrieved 12-VI-2018.

Camacho D. 2010. New insights on the genus Scolopendrelloides Bagnall, 1913 (Scuttigerellidae, Symphyla) with descripton of two new species // Zootaxa. Vol.2558. P.48-60.

Camacho D., VandenSpiegel D. 2012. Scolopendrellidae (Myriapoda, Symphyla) from the Afrotropics with description of seven new species // European Journal of Taxonomy. Vol.32. P.1-28.

Chamberlin R.V. 1920. The Myriapoda of the Australian region // Bulletin of the Museum of Comparative Zoology at Harvard College. Vol.64. No.1. P.3-270.

Clark S., Greenslade P. 1996. Review of Tasmanian Hanseniella Bagnall (Symphyla: Scutigerellidae) // Invertebrate Taxonomy. Vol.10. P.189-212.

Edwards C.A. 1959. Keys to the genera of the Symphyla // The Journal of the Linnean Society of London (Zoology). Vol.44. P.164-169

Hancock E.G. 1999. On the wild side: the natural history of the Glasgow botanical gardens // Glasgow Naturalist. Vol.23. No.4. P. 59-64.

Hansen H.J. 1903. The genera and species of the Order Symphyla // Quarterly Journal of Microscopical Science. Vol.47. No.1. P.1101.

Hilton W.A. 1943. A new Scutigerella from Tasmania // Journal of Entomology and Zoology. Vol.35. P.5-6.

Imms A.D. 1908. On a new species of Symphyla from the Himalayas // The Journal of the Linnean Society of London. Vol.30. P. 252-255.

Juberthie-Jupeau L. 1972. Contribution à l'étude des Symphyles (Myriapodes) d'Afrique du Sud // Bulletin du Muséum national d'Histoire naturelle, Paris. Série 3, Zoology. T.28. Fasc.34. P.329-334.

Juberthie-Jupeau L., Réveillet P. 1997. Un nouveax Symphyle (Myriopoda) de Colombie et considérations sur les appendices régénérés // Zoosystema. T.19. Fasc.4. P.613-622.

Jupeau L. 1955. Symphyles de Nosy-Bé et La Réunion // Mémoires de 1'Institut Scientifique de Madagascar. T.9A. P.105-127.

Lock K. 2010. Symphyla of Belgium // Entomologie Faunistique Faunistic Entomology. Vol.62. P.25-27. 
Michelbacher A.E. 1939. Further notes on Symphyla with descriptions of three new species from California // Annals of the Entomological Society of America. Vol.32. No.4. P.747-757.

Naumann I.D., Scheller U. 1977. The genus Millotellina Jupeau in Australia (Myriapoda: Symphyla: Scutigerellidae) // Journal of the Australian Entomological Society. Vol.16. P.47-57.

Nefediev P.S., Voigtländer K., Burkhardt U., Dekker P. 2016. The first records of Symphyla (Myriapoda) in Siberia, Russia // Arthropoda Selecta. Vol.25. No.2. P.153-155.

Olsen K.M., Lock K., Scheller U. 2014. Norwegian Symphyla // Norwegian Journal of Entomology. Vol.61. P.91-98.

Remy P. 1942. Quelques arthropodes intéressants des serres du Parc de la Tête d'Or // Bulletin mensuel de la Société linnéenne de Lyon. T.11. Fasc.9. P.140-142.

Ribaut H. 1914. Myriapodes II. Symphyla // Alluaud C., Jeannel R. (eds.). Voyage de Ch. Alluaud et R. Jeannel en Afrique Orientale 1911-1912. Résultats scientifiques. Librairie Albert Schulz, Paris. P39-48.

Rochaix B. 1956. Contribution à l'étude des Symphyles de Madagascar // Mémoires de l'Institut Scientifique de Madagascar. T.10A. P.231-244.

Scheller U. 1954. Symphyla from the Swedish East African Expeditions in 1937-1938 and 1948, with a summary of the known African species // Arkiv för zoologi. Vol.7. P.227-240.

Scheller U. 1961. A review of the Australian Symphyla (Myriapoda) // Australian Journal of Zoology. Vol.9. No.1. P.140-171.

Scheller U. 1971. Symphyla from Ceylon and Peninsular India // Entomologica Scandinavica, Supplementum 1. P.98-187.

Scheller U. 1979a. The Pauropoda and Symphyla of the Geneva Museum VI. Symphyla from Rhodesia and South Africa (Myriapoda) // Revue suisse de Zoologie. T.86. Fasc.4. P.947-95.

Scheller U. 1979b. Hanseniella arborea n. sp., a migrating symphylan from an Amazonian blackwater inundation forest (Myriapoda, Symphyla, Scutigerellidae) // Acta Amazonica. Vol.9. No.3. P.603-607.

Scheller U. 1986. Symphyla from the United States and Mexico // Texas Memorial Museum Speleological Monographs. No.1. P.87-126.

Scheller U. 1993. On the occurrence of the Symphyla in Venezuela with a description of a new species of Hanseniella Bagnall,
1913 (Arthropoda Myriapoda) // Tropical Zoology, Special Issue. Vol.1. P.141-146.

Scheller U. 1996. A new troglobitic species of Hanseniella Bagnall (Symphyla: Scutigerellidae) from Tasmania // Australian Journal of Entomology. Vol.35. P.203-207.

Scheller U. 2002. A new species of Hanseniella Bagnall (Myriapoda, Symphyla) found in a hothouse // Zoosystematics and Evolution. Vol.78. No.2. P.269-273.

Scheller U. 2007. New records of Pauropoda and Symphyla (Myriapoda) from Brazil with descriptions of new species in Allopauropus, Hanseniella and Ribautiella from the northern Pantanal wetland and from Mato Grosso of Brazil // Amazoniana. Bd.19. Nos 3/4. P.63-75.

Scheller U., Stoev P. 2006. First records of Symphyla (Myriapoda) from Bulgaria // Historia Naturalis Bulgarica. Vol.17. P.3537.

Scheller U., Wunderlich J. 2004. Two fossil symphylan species, Scutigerella baltica n.sp. and Hanseniella baltica n.sp. (Tracheata, Scutigerellidae), in Baltic amber // Stuttgarter Beiträge zur Naturkunde, Serie B (Geologie und Paläontologie). Bd.351. S.1-11.

Shaw H.K.A. 1961. Additions to the wild fauna and flora of the Royal Botanical Gardens, Kew, XXIV // Kew Bulletin. Vol.15. No.2. P.169-191.

Silvestri F. 1907. Nuova specie di Simfili Scutigerella ruwenzorii [A new species of Symphyla Scutigerella ruwenzorii] // Bollettino dei Musei di Zoologia ed Anatomia Comparata della R. Università di Torino. T.22. No.571. P.1-2.

Szucsich N., Scheller U. 2011. Symphyla // Minelli A. (ed.). Treatise on Zoology, Anatomy, Taxonomy, Biology. The Myriapoda. Volume 1. Brill: Leiden-Boston.

Tiegs O.W. 1939. Two new Victorian Symphyla of the genus Hanseniella // Memoirs of the National Museum Melbourne. Vol.11. P.5-10.

Voigtländer K., Decker P., Burkhardt U., Spelda J. 2017. An annotated checklist of Symphyla and Pauropoda (Myriapoda) of Germany // Staatliche Naturwissenschaftliche Sammlungen Bayerns, Munich.

Responsible editor S.I. Golovatch 


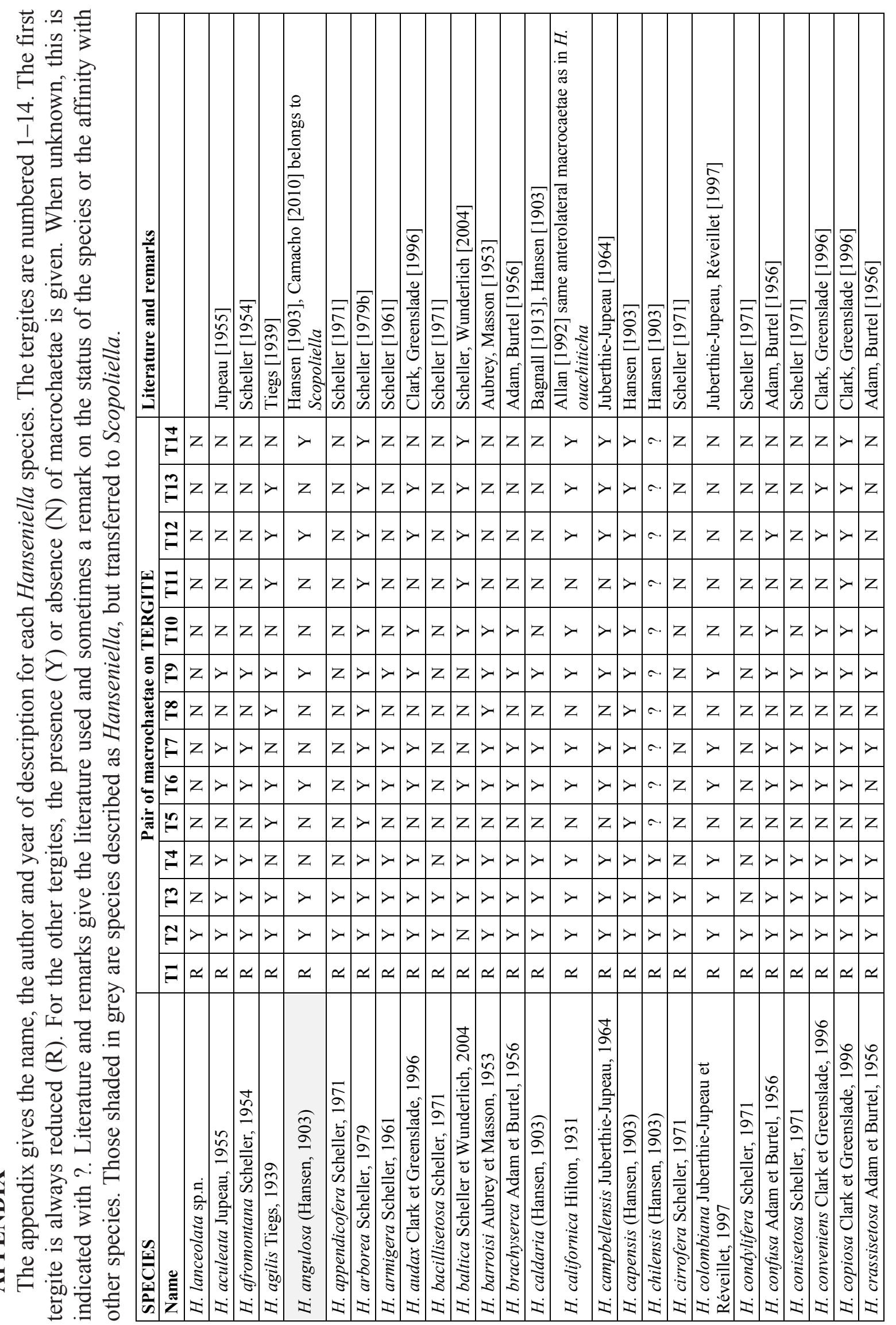




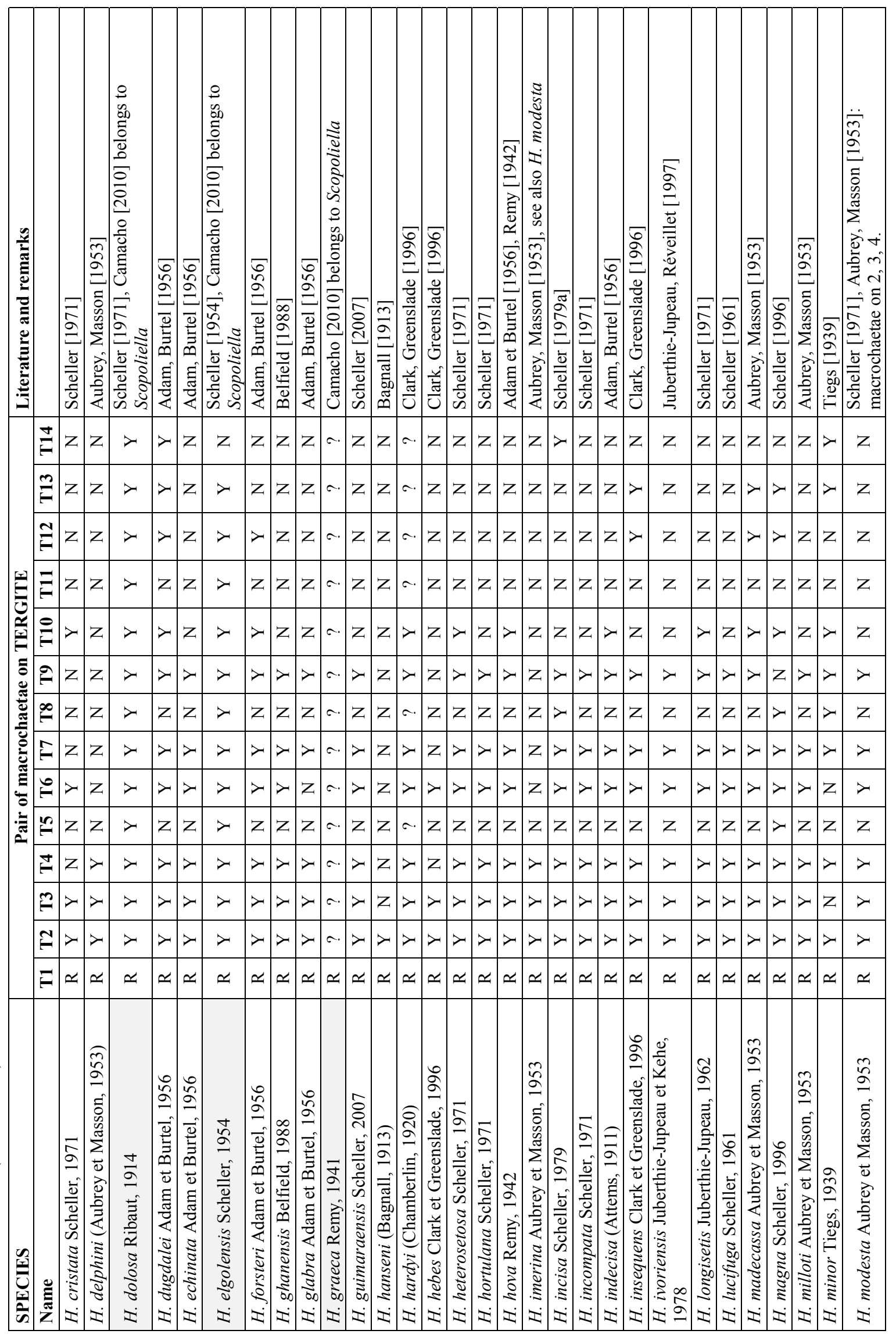




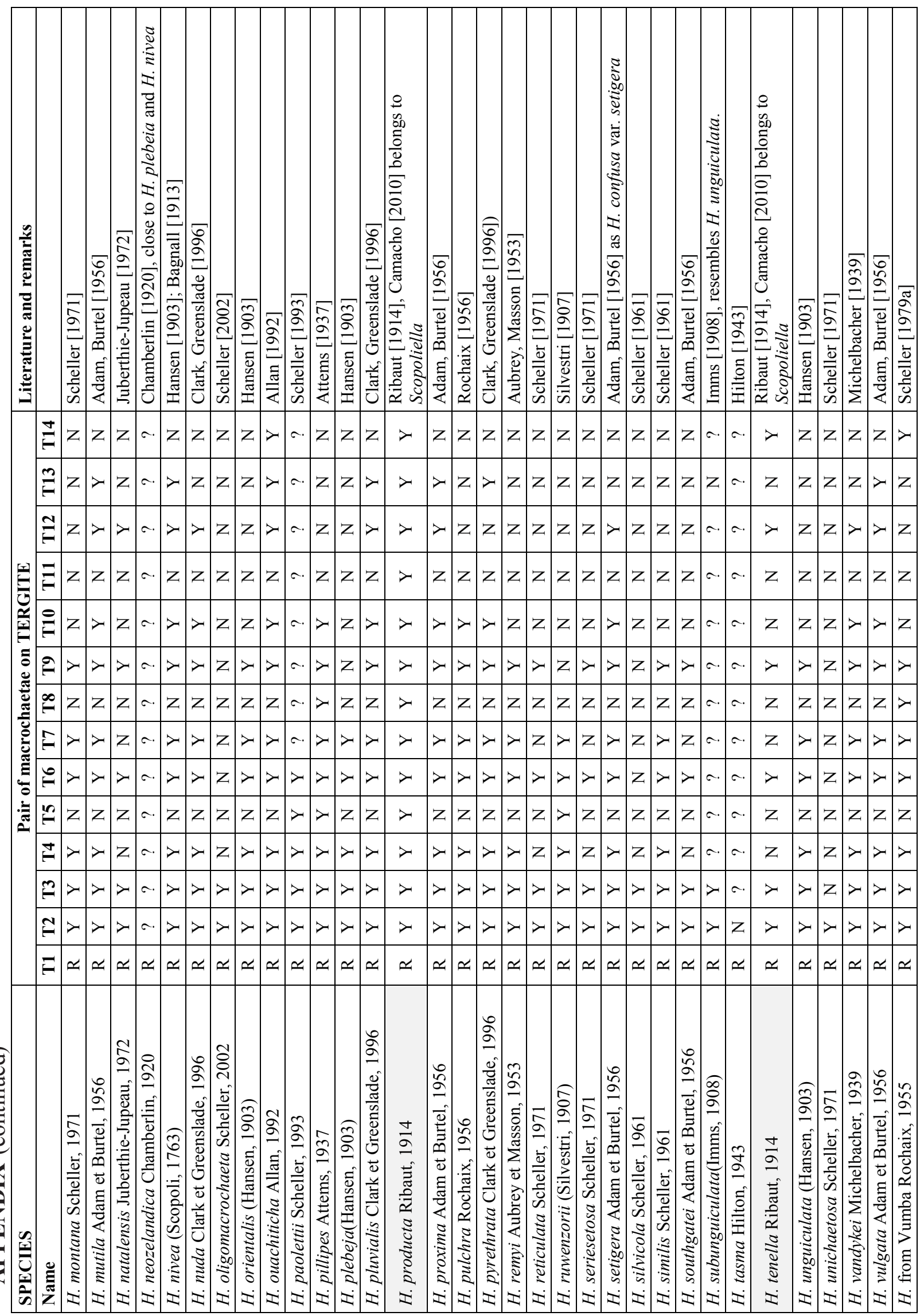

